\title{
MEKANISME REPLACEMENT CREW KAPAL GUNA MEMPERLANCAR CREWING MANAGEMENT DI PT. JASINDO DUTA SEGARA
}

\author{
Nur Rohmah ${ }^{\mathrm{a}}$, Adhi Pratistha Silen ${ }^{\mathrm{b}}$ dan Yusuf Sutrisno ${ }^{\mathrm{c}}$ \\ a dan b Dosen Program Studi KALK PIP Semarang \\ daruna (NIT. 50135074.K) Program Studi KALK PIP Semarang \\ *e-mail : yusufsutrisno26@gmail.com
}

\begin{abstract}
ABSTRAK
Diketahui bahwa replacement crew adalah kegiatan yang sangat penting terhadap kelancaran crewing management pada perusahaan crew manning agency. Dari hal tersebut, maka penulis tertarik untuk meneliti tentang "Mekanisme Replacement Crew Kapal guna Memperlancar Crewing Management di PT. Jasindo Duta Segara”. Penelitian ini menggunakan metode deskriftif kualitatif dengan mendeskripsikan secara terperinci mekanisme replacement crew kapal dalam menunjang crewing management di PT. Jasindo Duta Segara.

Hasil penelitian menunjukkan kendala-kendala yang dihadapi adalah control waiting list belum rapi, permintaan crew menddadak, pengarsipan dengan sistem manual dan sedikitnya minat crew bekerja pada perusahaan Korea. Upaya yang dilakukan adalah dengan mengupdate waiting list crew secara teratur, membuat kebijakan baru kepada ship owner, pengarsipan dengan sistem komputerisasi dan menyakinkan kepada crew kapal mengenai keuntungan bekerja pada perusahaan Korea dan memberikan masukan ke ship owner sebagai bahan evaluasi.
\end{abstract}

\section{Kata kunci: analisis, replacement crew kapal, crewing management}

\section{PENDAHULUAN}

\section{A. Latar Belakang}

Perkembangan dunia pelayaran, yang mulanya eksploitasi kemudian bergerak mengarah ke perdagangan dan industri yang dipelopori oleh negara-negara yang berasal dari Benua Eropa. Seiring berjalannya waktu terdapat pergeseran di negara-negara maju, dimana mereka tidak mau menjadi pelaut dan memilih untuk menjadi pelaku usaha atau industri. Menurut Engkos Kosasih dan Hananto Soewodo (2014:134), di negara-negara maju daya tarik kerja dilaut berkurang. Hal tersebut disebabkan oleh:

1. Dengan era kontainerisasi, jumlah hari di pelabuhan sangat singkat.

2. Jumlah crew di kapal semakin sedikit.

3. Gaji di kapal hampir sama dengan dengan gaji di darat dan terpisah dari keluarga.

Dari hal tersebut perusahaan di negaranegara maju mencari Sumber Daya Manusia
(SDM) pelaut ke negara-negara berkembang yang mempunyai banyak SDM pelaut, termasuk Indonesia.

Banyaknya permintaan SDM pelaut di negara-negara berkembang mengakibatkan munculnya perusahaan-perusahaan crew manning agency sebagai perwakilan dari perusahaan pelayaran luar negeri di Indonesia yang khusus mencari SDM pelaut, seperti halnya Jepang dan Korea. Mereka membutuhkan awak kapal dengan kualitas yang baik untuk dipekerjakan di atas kapal miliknya. Salah satu perusahaan perwakilan dari perusahaan pelayaran luar negeri di Indonesia adalah PT. Jasindo Duta Segara, yang bergerak di bidang keagenan awak kapal (crew manning agency). Crew Manning Agency adalah perusahaan yang hanya mengurusi pengawakan kapal untuk para ship owner di luar negeri. PT. Jasindo Duta Segara banyak berkerja sama dengan perusahaan asing yaitu perusahaan- 
perusahaan yang berasal dari negara-negara di Asia seperti Korea, Jepang dan Taiwan.

Data perusahaan pada bulan Juni 2016, PT. Jasindo Duta Segara menempatkan sebanyak 955 awak kapal dari Indonesia ke atas kapal milik ship owner. Jumlah tersebut belum ditambahkan dengan crew stand by yang sedang melaksanakan masa istirahat paska turun (sign off) dari kapal-kapal yang ditangani oleh PT. Jasindo Duta Segara yaitu yang berjumlah sekitar 500 crew kapal. Hal tersebut membuat aktivitas crew replacement pada perusahaan sangatlah padat, yaitu sebanyak 44 kali PT. Jasindo Duta Segara melaksanakan replacement crew kapal dalam jangka waktu sebulan. Oleh karena itu, PT. Jasindo Duta Segara dituntut dalam mekanisme pelaksanaan replacement crew kapal haruslah baik, guna untuk memperlancar crewing management yang akan membuat kerjasama dengan ship owner semakin baik.

Pada saat penulis melaksanakan praktek darat di PT. Jasindo Duta Segara selama kurang lebih 10 bulan, dari bulan Juli sampai dengan Juni 2016 masih terdapat pelaksanaan mekanisme replacement crew kapal yang belum berjalan secara baik sehingga perlu perbaikan. Misalnya, pengarsipan dengan sistem filling cabinet, special case permintaan replacement crew yang mendadak, masalah pada control waiting list dan sedikitnya crew kapal yang bersedia bekerja dengan crew asal Korea yang dapat menghambat proses pelaksanaan mekanisme crew replacement pada perusahaan. Perusahaan sudah melakukan beberapa upaya perbaikan berkaitan dengan kendala-kendala tersebut tetapi belum memberikan hasil yang maksimal sehingga masih perlu dilakukan perbaikan. Berdasarkan latar belakang tersebut penulis tertarik membuat penelitian dengan judul "Analisis Mekanisme Replacement Crew Kapal guna Memperlancar Crewing Management di PT. Jasindo Duta Segara".

\section{B. Perumusan Masalah}

Dalam pembahasan ini, maka peneliti merumuskan permasalahannya sebagai berikut:

1. Kendala apa yang dihadapi dalam pelaksanaan mekanisme replacement crew kapal guna memperlancar crewing management di PT. Jasindo Duta Segara?

2. Upaya apa yang dilakukan untuk mengatasi kendala-kendala yang dihadapi dalam pelaksanaan mekanisme replacement crew kapal guna memperlancar crewing management di PT. Jasindo Duta Segara?

\section{KAJIAN PUSTAKA}

\section{B. Tinjauan Pustaka}

4. Mekanisme

Menurut Moenir (2012), mekanisme adalah suatu rangkaian kerja sebuah alat yang digunakan dalam menyelesaikan sebuah masalah yang berkaitan dengan proses kerja, tujuannya adalah untuk menghasilkan hasil yang maksimal serta mengurangi kegagalan.

5. Replacement

Menurut Engkos Kosasih dan Hananto Soewodo (2014:131-133), ada perusahaan pelayaran yang menganut sistem pengawakan sebagai laut tetap, seperti umumnya di Badan Usaha Milik Negara (BUMN). Namun banyak perusahaan yang menganut sistem pengawakan secara kontrak seperti umumnya pada perusahaan swasta. Khusus untuk perusahaan swasta yang menganut pegawai tetap, perlu dipikirkan adanya ABK dan Nakhoda cadangan di darat yang jumlahnya kurang lebih 25-50\% aktif, tergantung besarnya perusahaan, sebagai cadangan untuk pengganti (mutasi naik atau turun), ABK cuti, sakit, pendidikan, dan sebagainya. 
a. Syarat untuk dapat bekerja di kapal adalah memiliki:

1) Sertifikat Keahlian5 Pelaut dan Sertifikat Ketrampilan Pelaut.

2) Perjanjian Kerja Laut (PKL) antara perusahaan pelayaran dengan awak kapal yang disyahkan oleh syahbandar.

3) Sijil Awak Kapal.

4) Sertifikat Kesehatan Pra Berlayar.

5) Buku Pelaut.

b. Terjadinya pergantian awak kapal di atas kapal (mutasi naik turun) disebabkan beberapa kemungkinan, yaitu:

1) Cuti.

2) Atas Permintaan Sendiri

3) Menunggu penempatan dan Standby.

4) Sakit.

5) Habis masa kontrak, dan sebagainya.

6) Pemeriksaan kesehatan sampai mendapatkan surat sehat.

7) Mengikuti diklat kepelautan.

8) Mengurus surat-surat yang habis masa berlakunya atau revalidasi (passport, buku pelaut, sertifikat ketrampilan, dan sebagainya).

6. Crew Kapal

Menurut Undang-Undang RI No.17 Tahun 2008 tentang Pelayaran Bab I Ketentuan Umum Pasal 1 Ayat 40, "Awak Kapal adalah orang yang bekerja atau dipekerjakan di atas kapal oleh pemilik atau operator kapal untuk melakukan tugas di atas kapal sesuai dengan jabatannya yang tercantum dalam buku sijil". Semua posisi di kapal dari Kapten sampai Messboy adalah awak kapal. Dalam ayat 41 disebutkan bahwa "Nahkoda adalah salah seorang dari awak kapal yang menjadi pemimpin tertinggi di kapal dan mempunyai wewenang dan tanggung jawab tertentu sesuai dengan ketentuan peraturan perundangundangan, dan pada ayat 42 Nahkoda cukup di istimewakan oleh Undang-
Undang Negara yang berbunyi, “Anak Buah Kapal adalah Awak Kapal selain Nahkoda".

7. Crewing atau Pengawakan Menurut Peraturan Menteri Perhubungan Republik Indonesia Nomor PM 84 Tahun 2013 Tentang Perekrutan dan Penempatan Awak Kapal pada BAB I Ketentuan Umum Pasal 1 Ayat 1, 2, dan 3 dalam peraturan ini yang dimaksud dengan:

a. Perusahaan Angkutan Laut adalah perusahaan angkutan laut berbadan hukum Indonesia yang melakukan kegiatan angkutan laut di dalam wilayah perairan Indonesia dan atau dari dan ke pelabuhan di luar negeri.

b. Usaha Keagenan Awak Kapal (Ship Manning Agency) adalah usaha jasa keagenan awak kapal yang berbentuk badan hukum yang bergerak di bidang rekrutmen dan penempatan awak kapal di atas kapal sesuai kualifikasi.

c. Serikat Pekerja adalah organisasi pekerja yang sesuai dengan ketentuan nasional dan atau organisasi pekerja internasional dengan serikat pekerja atau serikat buruh internasional.

\section{Manajemen}

Menurut George R. Terry dalam buku Engkos Kosasih dan Hananto Soewodo (2014:1), manajemen adalah pencapaian tujuan yang telah ditetapkan sebelumnya melalui usaha orang lain. Dalam hal ini adalah tata kelola yang digunakan dalam pelaksanaan crewing management guna memperlencar replacement crew kapal di PT. Jasindo Duta Segara.

\section{Kerangka Pikir Penelitian}

Untuk dapat memaparkan pembahasan penelitian ini, peneliti membuat suatu kerangka pemikiran terhadap hal-hal yang menjadi pembahasan mengenai penelitian ini. 


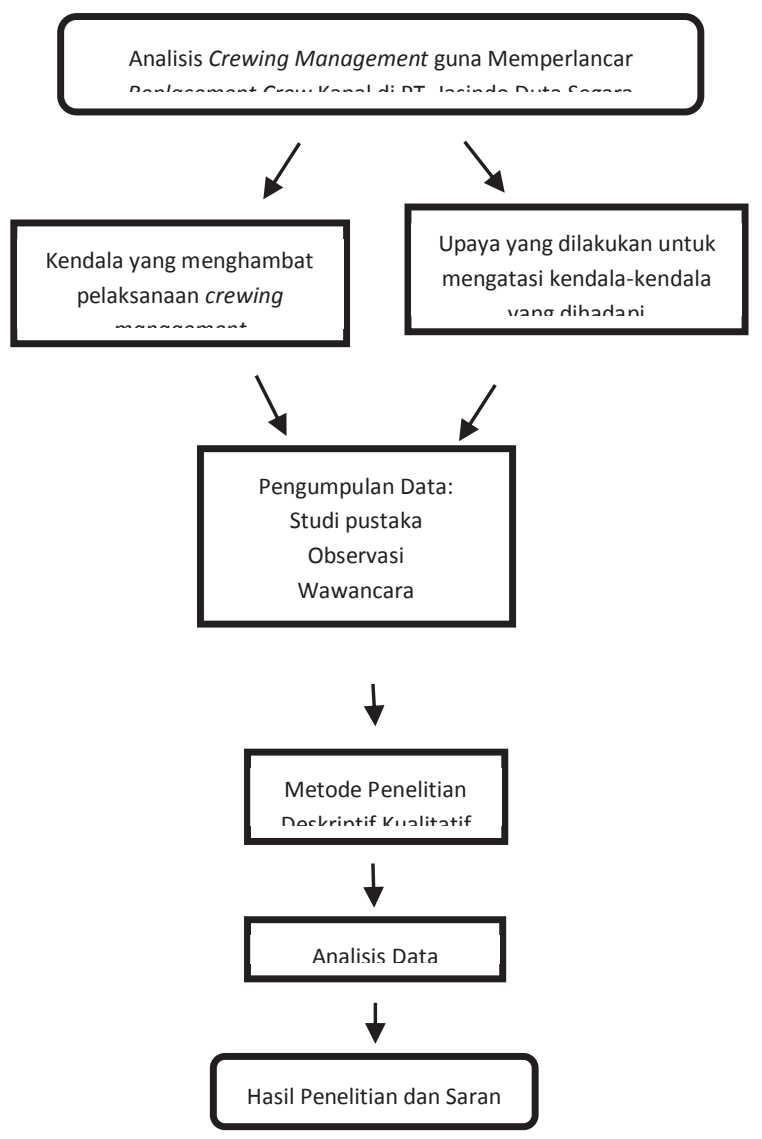

Gambar 1. Kerangka Pikir

\section{METODOLOGI}

\section{A. Metode Penelitian}

\section{Metode Deskiftif}

Dalam penelitian ini digunakan metode penelitian secara deskriptif. Yang dimaksud deskriptif adalah berusaha menggambarkan dan menginterpretasi objek sesuai apa adanya, dengan tujuan menggambarkan secara sistematis fakta dan karakteristik objek yang diteliti secara tepat.

2. Metode Kualitatif

Menurut Moelong (2006:6), penelitian kualitatif adalah penelitian yang bermaksud untuk memahami fenomena tentang apa yang dialami oleh subjek penelitian, misalnya perilaku, persepsi, motivasi, tindakantindakan dan lain-lain, secara holistik dengan cara deskripsi dalam bentuk kata-kata dan bahasa pada suatu konteks khusus alamiah dengan memanfaatkan berbagai metode ilmiah. Sementara itu Kirk dan Muller mendefinisikan bahwa penelitian kualitatif adalah tradisi tertentu dalam ilmu pengetahuan sosial yang secara fundamental bergantung pada pengamatan terhadap manusia dalam kawasannya sendiri dan berhubungan dengan orang-orang tersebut.

\section{B. Lokasi dan Waktu Penelitian}

Penelitian skripsi ini dilaksanakan di PT.Jasindo Duta Segara yang beralamatkan di Jl. Jalan Raya Boulevard Barat, Plaza Kelapa Gading, Rukan Blok C / 55, Kelapa Gading, Jakarta, Indonesia pada tanggal 28 Juli 2015 sampai dengan tanggal 30 Juni 2016 pada saat peneliti melaksanakan praktek darat.

\section{Metode Pengumpulan Data}

1. Metode Observasi

Observasi diartikan sebagai pengamatan dan pencatatan secara sistematik terhadap gejala yang tampak pada obyek penelitian. Pengamatan dilakukan di tempat terjadinya peristiwa, sehingga obsevasi berada bersama obyek. Dalam penelitian ini observasi dilakukan dalam mekanisme pelaksanaan replacement crew kapal guna memperlancar crewing management di PT. Jasindo Duta Segara.

\section{Metode Komunikasi}

Teknik komunikasi adalah cara mengumpulkan data melalui kontak atau hubungan pribadi antara pengumpul data dengan sumber data. Dalam pengumpulan data pada penelitian ini menggunakan teknik komunikasi secara langsung yaitu teknik pengumpulan data dengan menggunakan wawancara sebagai alatnya. Untuk mendapatkan informasi data yang tepat dan obyektif harus mampu menciptakan hubungan baik dengan sumber informasi ,yang 
dalam penelitian ini sebagai sumber informasi adalah para pegawai kantor dan crew kapal di PT. Jasindo Duta Segara.

3. Metode Studi Pustaka

Menurut Sukardi (2003:33) studi pustaka adalah menelusuri dan mencari dasar-dasar acuan yang erat kaitannya dengan masalah penelitian yang hendak dilakukan, dasar-dasar tersebut tidak terbatas dari satu sumber saja tetapi dapat di cari dari berbagai sumber kemudian disusun dalam bab sendiri. Studi pustaka merupakan metode pengumpulan berbagai informasi dan referensi lain yang dilakukan di dalam perpustakaan dengan cara merangkum dan mencatat serta mempelajari buku-buku yang diterbitkan oleh Politeknik Ilmu Pelayaran (PIP) Semarang, serta sumber referensi lain.

\section{Teknik Analisis Data}

1. Reduksi data

Reduksi dalam hal ini adalah cara memformulasikan teori kedalam seperangkat konsep yang tinggi tingkatan abstraksinya atas dasar keseragaman dari seperangkat kategori. Data yang ada dipelajari dan dilakukan pembatasan teori sehingga menjadi padat dan berisi dengan mengeluarkan data yang tidak relevan, mengintegrasikan kawasan yang kecilkecil ke dalam kerangka kategori yang berkaitan.

2. Penyajian data

Penyajian data yang dimaksud adalah sebagai proses analisis untuk merakit temuan data dilapangan dalam bentuk apapun deskriptif satuan kategori bahan dari yang umum menuju yang khusus. Penyajian data tersebut dengan mengelompokkan responden dan perilakunya, serta bagaimana perbedaannya sehingga dapat menemukan tema dan pembentukan hipotesis yang dibuat dengan cepat.
3. Menarik kesimpulan

Menarik simpulan merupakan kemampuan seorang peneliti dalam menyimpulkan berbagai temuan data yang diperoleh selama proses penelitian berlangsung.

\section{DISKUSI}

\section{B. Gambaran Umum Obyek yang Diteliti}

PT. Jasindo Duta Segara merupakan perusahaan yang bergerak pada bidang keagenan awak kapal (crew manning agency). Crew manning agency adalah perusahaan yang hanya mengurusi pengawakan kapal untuk para ship owner dari luar negeri. PT. Jasindo Duta Segara berkerjasama dengan perusahaanperusahaan yang berasal dari negaranegara Asia seperti Korea, Jepang dan Taiwan, diantaranya H-Line Shipping, STX Marine Service, Osaka Asahi Kaiun, World Marine, Korean Marine Craft (KMC), Evergreen, Cosmo SeaLand, Growwill, Pos Shipp Management, S SK Shipping, Imsco dan Dintec.

\section{Mekanisme Pelaksanaan Replacement Crew Kapal di PT. Jasindo Duta Segara}

Tahapan atau proses replacement crew pada PT. Jasindo Duta Segara guna untuk memperlancar crewing management adalah sebagai berikut:

1. Tahap permintaan crew

Tahapan ini merupakan tahapan pertama dari replacement crew dimana kapten kapal mengirimkan email permintaan sign off kepada ship owner serta PT. Jasindo Duta Segara sebelum masa kontrak crew kapal yang bersangkutan berakhir. Hal ini bertujuan agar perusahaan bisa mempersiapkan crew kapal pengganti dengan baik dan sesuai kriteria yang diminta oleh Kapten dan ship owner.

2. Tahap prepare crew pengganti

Tahapan ini akan berjalan setelah perusahaan menerima e-mail (yang sudah disetujui oleh ship owner) dari 
kapal untuk permintaan pergantian crew. Setelah menerima e-mail, Recruiting Manager langsung mencari crew kapal pengganti yang sesuai dengan permintaan dari ship owner. Ada dua cara dalam mencalonkan crew kapal ke ship owner yaitu dengan mencalonkan ex crew dan melakukan perekrutan crew baru apabila tidak ada crew stand by sesuai kebutuhan.

3. Tahap pengiriman data ke ship owner

Soft file data dikirim ke ship owner melalui e-mail dengan menyebutkan keterangan yang jelas seperti nama kapal, rencana jadwal replacement dan menyampaikan hambatan mengenai crew tersebut.

4. Tahapan persiapan dan pengarsipan dokumen

a. Persiapan dokumen

Tahapan ini dijalankan setelah crew kapal pengganti yang dicalonkan oleh recruiting manager mendapatkan approval dari ship owner. Dokumen yang harus dipersiapkan untuk sign on berbeda-beda sesuai dengan jabatan dari crew kapal tersebut.

b. Pengarsiapan dokumen

Pengarsipan dokumen dilakukan oleh Taruna yang melaksanakan praktek darat dan dicek langsung oleh Operational Manager. Pengarsipan dilakukan dengan cara melakukan photo copy semua dokumen crew kapal yang akan sign on dan kemudian dimasukkan ke dalam map terpisah dari masingmasing crew kapal. Pengarsipan bertujuan untuk back up data perusahaan apabila sewaktu-waktu dibutuhkan.

5. Tahap medical check up, education \& training dan penandatanganan dokumen terkait

Beberapa hari sebelum jadwal keberangkatan sign on, crew kapal wajib mengikuti beberapa kegiatan, yaitu medical ceck up, education \& training dan penandatanganan dokumen terkait. Medical ceck up dilaksanakan di rumah sakit Puri Medika atau Jakarta Marindo yang terletak di Tanjung Priok yang bertujuan untuk mengetahui kesehatan crew kapal. Education \& training crew kapal dilaksanakan selama empat hari yang bertempat di PT. Jasindo Duta Segara dengan pengampu yaitu Education \& Training Manager, sedangkan dokumen-dokumen yang wajib ditandatangani oleh crew kapal yang akan sign on adalah PKL, Crew Of Employment (COE), Education \& Training Certificate (Pre Joining).

6. Tahap pergantian crew

Tahap ini adalah proses sign on crew pengganti dan sign off crew yang akan digantikan. Keberangkatan ataupun kepulangan crew akan dilakukan pengantaran dan penjemputan ke Bandara Soekarno Hatta oleh staf operasional.

\section{Analisa Masalah}

Di dalam bagian analisis masalah ini penulis menjelaskan tentang kendala dan upaya yang dihadapi oleh PT. Jasindo Duta Segara dalam pelaksanaan replacement crew kapal guna memperlancar crewing management. Analisis masalah bertujuan untuk memberikan jawaban dari rumusan masalah yang telah disusun, yaitu tentang eendala apa yang dihadapi dalam pelaksanaan mekanisme replacement crew kapal guna memperlancar crewing management dan upaya apa yang dilakukan untuk mengatasi kendalakendala yang dihadapi dalam pelaksanaan mekanisme replacement crew kapal guna memperlancar crewing management di PT. Jasindo Duta Segara.

Kelancaran proses replacement crew di PT. Jasindo Duta Segara sangat berpengaruh terhadap crewing management yang dijalankan oleh perusahaan. Pelaksanaan replacement crew kapal melibatkan beberapa pihak, 
yaitu ship owner, crew kapal dan perusahaan yang terdiri dari seluruh divisi yang ada pada perusahaan. Oleh karena itu membutuhkan komunikasi dan koordinasi yang baik dari semua pihak yang terlibat. Berdasarkan hasil pengamatan pada saat peneliti melaksanakan praktek darat di PT. Jasindo terdapat masalah-masalah yang menjadi kendala pada pelaksanaan replacement crew kapal, yaitu sebagai berikut:

1. Control waiting list kapal yang belum rapi

Control waiting list merupakan data yang digunakan sebagai pedoman oleh Deck/Engine Manager untuk memilih kandidat yang akan dicalonkan ke ship owner. Data tersebut berbentuk exel yang secara dan pengolahannya dengan memisahkan crew stand by dari masing-masing ship owner. Data tersebut jarang dilakukan update sehingga mengganggu rolling crew plan. Upaya yang dilakukan perusahaan adalah dengan mewajibkan Deck/Engine Manager untuk selalu mengupdate data tersebut.

2. Permintaan crew kapal yang mendadak

Kualitas crew di atas kapal sangat dipengaruhi oleh pelaksanaan rekrutmen awal pada saat crew tersebut melaksanakan rangkaian seleksi. Permintaan crew kapal yang mendadak membuat keterbatasan waktu perusahaan untuk menyiapkan segala sesuatunya. Tidak hanya dari segi perekrutan, permintaan crew kapal yang mendadak juga sangat mempengaruhi proses pada tahapan prepare document. Dengan waktu yang singkat rawan terjadi kekeliruan pada saat prepare document karena tidak sedikitnya dokumen yang harus dipersiapkan. Langkah yang diambil perusahaan adalah dengan membuat kebijakan kepada ship owner, bahwa permintaan crew kapal harus dikirimkan dua bulan sebelum jadwal replacement.

3. Pengarsipan masih dengan sistem filling cabinet dan kardus

Pengarsipan dengan sistem filling cabinet membuat kegiatan pengarsipan menjadi pekerjaan yang melelahkan (memindahkan, menyortir, melubangi kertas, merapikan, menandai dan menyimpan). Saat dokumen dibutuhkan, mencari dokumen menjadi hal yang sangat sulit. Butuh waktu dan tenaga untuk mencarinya. Kardus arsip semakin memenuhi ruangan sehingga mengganggu kenyamanan bekerja. Upaya yang dilakukan perusahaan adalah dengan melakukan scan pada dokumen dan mengelompokkan ke dalam folder berdasarkan jabatan dari crew tersebut.

4. Sedikitnya minat crew kapal asal Indonesia untuk berkerja dengan perusahaan asal Korea

Dari banyaknya jumlah crew yang dimiliki perusahaan, hal yang menjadi penghambat dalam pencalonan crew kapal adalah sedikitnya crew kapal asal Indonesia yang mau bekerja dengan crew asal Korea. Hal ini disebabkan karena jumlah gaji pada perusahaan Korea relatif lebih rendah dibandingkan perusahaan asal Jepang. Penyebab lainnya adalah banyaknya keluh kesah dari crew kapal yang pernah join pada perusahaan Korea yaitu sistem kerja yang memberatkan sehingga banyak crew kapal yang menolak untuk bekerja pada perusahaan Korea. Upaya yang dilakukan oleh perusahaan adalah dengan menjelaskan dan menyakinkan kepada crew kapal asal Indonesia tentang keuntungan bekerja dengan perusahaan asal Korea dan memberikan masukan kepada ship owner sebagai bahan evaluasi agar bisa memenuhi apa yang crew kapal inginkan. 


\section{Hasil Penelitian}

1. Kendala apa yang dihadapi dalam pelaksanaan mekanisme replacement crew kapal guna memperlancar crewing management di PT. Jasindo Duta Segara?

Berdasarkan

observasi, dokumentasi dan hasil wawancara mendalam yang dilakukan dengan beberapa karyawan, maka dapat diperoleh beberapa kendala yang menghambat dalam pelaksanaan replacement crew kapal di PT. Jasindo Duta Segara adalah sebagai berikut:

a. Control waiting list yang belum rapi

Pada bulan Juni 2016 PT. Jasindo Duta Segara melaksanakan kegiatan replacement crew kapal sebanyak 44 kali dalam waktu sebulan. Tetapi hal tersebut tidak didukung dengan pengolahan control waiting list crew yang rapi. Deck/Engine Manager selaku penanggung jawab hal tersebut jarang melaksanakan update crew stand by. Hal ini membuat tahap pencalonan crew kapal ke ship owner tidak berjalan secara adil dan merata. Banyak crew kapal yang mengeluh karena terlalu lama di darat menunggu panggilan on board tetapi belum mendapatkan panggilan karena crew kapal tersebut tidak ada dalam waiting list crew yang dimiliki Deck/Engine Manager pada saat crew kapal tersebut sign off dari kapal sebelumnya.

Salah satu penyebab hal tersebut adalah dikarenakan kesadaran crew kapal untuk segera laporan ke perusahaan setelah sign off sangatlah rendah. Banyak crew kapal yang setelah sign off memilih untuk berlibur bersama keluarga terlebih dahulu dibandingkan langsung melapor ke perusahaan. Padahal tujuan laporan ke perusahaan salah satunya adalah untuk konfirmasi kesiapan join pada kapal selanjutnya.

Dari hal tersebut dapat peneliti simpulkan bahwa tidak rapinya crew waiting list sangatlah menghambat dalam kelancaran pelaksanaan replacement crew kapal dan sangat mempengaruhi kelancaran crewing management yang dijalankan oleh perusahaan dan perlu penanganan serius untuk kemajuan perusahaan.

b. Permintaan crew kapal yang mendadak

PT. Jasindo Duta Segara beberapa kali melaksanakan perekrutan crew secara cepat karena urgent. Hal ini membuat suasana dalam bekerja menjadi tidak kondusif dan mengakibatkan staf yang bertanggung jawab dalam hal itu kurang memperhatikan kualitas dari crew yang dibutuhkan karena perekrutan lebih diprioritaskan pada persyaratan administratif, seperti dokumen, pengalaman berdasarkan seaman book dan kurang memperhatikan kualitasnya. Sistem perekrutan seperti ini kurang efektif karena sangat rawan terhadap pemalsuan pengalaman yang ada pada seaman book tersebut.

Kendala perusahaan untuk mempersiapkan crew pengganti adalah mepetnya $e$-mail permintaan replacement crew dari ship owner ke perusahaan, hal tersebut membuat perusahaan kalang kabut dalam mempersiapkan crew pengganti, belum lagi kalau tidak ada stok crew yang sesuai permintaan. Tentu perusahaan harus mencari crew kapal baru dari pelamar yang prosesnya cukup lama ditambah kriteria crew kapal yang diminta owner sangatlah tinggi. Hal yang diakibatkan dari permintaan crew kapal yang mendadak adalah beberapa kali 
perusahaan tidak bisa melaksanakan replacement crew karena belum mempunyai crew pengganti.

Operational Department yang bertanggung jawab masalah prepare document juga selalu dipusingkan dengan sangat singkatnya waktu dalam mempersiapkan dokumen crew kapal, hal itu dikarenakan sering terjadi permintaan crew mendadak dari ship owner, belum lagi kalau crew yang dicalonkan sertifikatnya belum lengkap dan perlu pengurusan, staf operasional sangat kerepotan mengurus itu semua. waktu yang staf butuhkan dalam pengurusan dokumen crew on board seperti PKL (Perjanjian Kerja Laut), Sijil seaman book, KPI (Kesatuan Pelaut Indonesia) membutuhkan waktu yang lama karena pengurusan berada pada tempat yang berbeda.

Permintaan crew yang mendadak akan berakibat pada waktu edukasi dan pelatihan terhadap crew menjadi sangat singkat, beberapa kali perusahaan mengizinkan crew kapal on board tanpa dilakukan education \& tarining terlebih dahulu, pernah juga dipersingkat hanya 2 (dua) hari yang seharusnya dilakukan 4 (empat) hari. Hal yang perusahaan takutkan adalah hal tersebut akan berakibat pada kualitas crew di atas kapal yang tidak sesuai dengan harapan dan akan merugikan perusahaan dan ship owner.

c. Pengarsipan masih dengan sistem filling cabinet dan kardus

PT. Jasindo Duta Segara merupakan perusahaan yang telah didukung dengan sarana komputer yang memadahi, mulai dari fasilitas untuk karyawan kantor ataupun untuk crew kapalnya. Tetapi hal tersebut tidak didukung dengan pengelolaan sistem yang baik. Masih banyak kegiatan pengarsipan dilakukan dengan sistem manual. Hal ini karena PT. Jasindo Duta Segara masih menggunakan sistem pengarsipan dokumen secara print out berupa kertas dan dilakukan penyimpanan di dalam sebuah lemari perusahaan (fiilling cabinet) sehingga membuat kegiatan pengarsipan menjadi pekerjaan yang melelahkan (memindahkan, menyortir, melubangi kertas, merapikan, menandai dan menyimpan). Belum lagi saat pencarian dokumen yang sangat memusingkan kepala. Butuh waktu dan tenaga untuk mencarinya di dalam filing cabinet. Kardus arsip juga semakin memenuhi ruangan sehingga mengganggu kenyamanan bekerja.

d. Sedikitnya minat crew kapal untuk berkerja pada perusahaan Korea

Berdasarkan pengamatan yang dilakukan peneliti saat melaksanakan praktek darat, sering terjadi penolakan penawaran on board dari perusahaan oleh crew kapal karena crew kapal tersebut tidak mau dicalonkan pada kapalkapal dari perusahaan Korea. Capt. Agustino selaku Recruiting Manager pada PT. Jasindo Duta Segara mengatakan bahwa kesulitan perusahaan untuk penempatan crew kapal adalah kurangnya minat crew kapal dari Indonsia untuk bekerja pada perusahaan asal Korea, karena banyak dari crew kapal asal Indonesia khususnya crew kapal PT. Jasindo Duta Segara yang mengganggap bekerja pada perusahaan asal Korea sangatlah berat. Beberapa kali setiap perusahaan menelpon crew stand by yang seharusnya sudah siap untuk on board rela menunda keinginannya untuk kembali 
bekerja ke atas kapal karena menolak dipekerjakan pada kapal milik perusahaan Korea.

Hal tersebut diperkuat dengan hasil wawancara peneliti dengan Bpk. Aris yang bekerja sebagai $A B$ pada kapal yang ditangani PT. Jasindo Duta Segara yaitu, pada perusahaan Korea sangat tidak nyaman, Crew kapal asal Korea memiliki sifat kerja dengan sistem penekanan terhadap bawahan. Hal lain yaitu gaji pada perusahaan Korea relatif lebih rendah dari pada perusahaan Jepang. Selisih pada jabatan $A B$ mencapai US \$200. Total selisih tersebut bisa untuk biaya hidup selama di darat. Perlu penyetaraan pelayanan yang harus diberikan oleh perusahaan Korea terhadap crew kapal yang bekerja di kapal perusahaan Korea supaya kesejahteraan pelaut bisa terpenuhi dengan baik.

Capt. Agus Susanto selaku Deck Manager menambahkan, hal tersebut sangatlah merugikan bagi perusahaan dan ship owner, dimana perusahaan dituntut untuk kembali melakukan perekrutan crew baru karena tidak adanya ex crew yang bersedia untuk dipekerjakan ke kapal-kapal milik perusahaan Korea. Padahal crew tersebut sudah tentu mempunyai kualitas yang baik dan sangat berpengalaman. Berbeda dengan kualitas crew baru yang belum perusahaan ketahui secara langsung.

Dari beberapa hasil wawancara di atas dapat disimpulkan bahwa faktor yang membuat sedikitnya minat crew kapal untuk bekerja pada perusahaan Korea yaitu tingginya tekanan saat bekerja dari crew kapal asal Korea dan lebih rendahnya gaji pada perusahaan Korea dibandingkan perusahaan asal Jepang dan perlu adanya perbaikan dengan penyetaraan gaji antara perusahaan Korea dengan perusahaan Jepang yang diberikan kepada crew kapal khususnya pada jabatan Rating dan sangat menghambat pelaksanaan replacement crew kapal di PT. Jasindo Duta Segara.

2. Upaya apa yang dilakukan untuk mengatasi kendala-kendala yang dihadapi dalam pelaksanaan mekanisme replacement crew kapal guna memperlancar crewing management di PT. Jasindo Duta Segara?

Berdasarkan observasi yang dilakukan, agar pelaksanaan crewing management kapal berjalan dengan lancar, PT. Jasindo Duta Segara telah melakukan beberapa upaya sebagai berikut:

a. Mengupdate waiting list crew secara teratur

Memperbarui data control waiting list harus dilakukan oleh Deck/Engine Manager selaku penanggung jawab agar rolling plan crew berjalan sebagaimana mestinya. Perlu dihimbau juga terhadap crew kapal yang sudah sign off untuk merlapor secepatnya ke kantor setelah sampai di Indonesia sehingga proses mengupdate waiting list crew bisa berjalan dengan lancar dan akurat karena dalam proses tersebut membutuhkan data seperti berapa lama crew kapal tersebut siap untuk on board kembali ke kapal berikutnya. Diupdatenya waiting list crew secara teratur, akan mempermudah dalam memonitor crew rolling plan dan pelaksanaan mekanisme replacement crew kapal bisa berjalan dengan baik yang berpengaruh terhadap lancarnya crewing management yang dijalankan oleh PT. Jasindo Duta Segara.

b. Membuat kebijakan kepada ship owner agar permintaan replacement 
crew kapal dikirimkan dua bulan sebelum masa keberangkatan crew pengganti

Proses persiapan replacement crew kapal merupakan suatu kegiatan yang membutuhkan waktu relatif lama dan diperlukan ketelitian mengenai prepare dokumen. Berdasarkan beberapa kejadian yang berkaitan dengan mendadaknya waktu permintaan replacement crew kapal dari ship owner, perusahaan membuat sebuah kebijakan kepada ship owner agar permintaan replacement crew harus dikirimkan dua bulan sebelum masa keberangkatan crew kapal pengganti. Hal ini akan membuat proses mempersiapkan crew kapal menjadi maksimal dan mempengaruhi terhadap kualitas crew kapal yang didapatkan.

c. Pengarsipan dokumen menggunakan sistem scan dan pengelompokan soft file berdasarkan jabatan

Upaya ini menjadikan kegiatan pengarsipan berjalan dengan baik. Staf operasional bisa mendapatkan data/dokumen yang dibutuhkan dalam waktu yang singkat. Suasana ruanganpun menjadi nyaman karena terhindar dari tumpukantumpukan kertas seperti sebelumsebelumya. Hal ini membuat biaya pengeluaran perusahaan untuk pembelian kertas menjadi lebih kecil dan pemanfaatan komputer bisa berjalan dengan baik.

d. Menjelaskan dan menyakinkan kepada crew kapal mengenai keuntungan bekerja pada perusahaan Korea dan memberikan masukan ke ship owner sebagai bahan evaluasi

Sedikitnya minat crew kapal untuk berkerja pada kapal-kapal yang berasal dari perusahaan Korea merupakan salah satu hal yang menghambat mekanisme pelaksanaan replacement crew karena perusahaan memiliki stok crew kapal stand by yang siap untuk on board tetapi tidak mau dicalonkan pada perusahaan Korea. Hal ini karena crew Indonesia lebih memilih pada perusahaan Jepang yang memiliki gaji lebih tinggi. Langkah yang diambil perusahaan adalah dengan menjelaskan dan menyakinkan crew kapal mengenai keuntungan bekerja pada perusahaan Korea, salah satunya adalah karir yang lebih cepat. Melalui Wawancara terbuka dengan Capt. Agustino selaku Recruiting Manager, peneliti mendapatkan informasi sebagai berikut, Perusahaan telah melakukan beberapa langkah untuk mengatasi hal ini, yaitu dengan menjelaskan dan menyakinkan kepada crew kapal mengenai keuntungan bekerja pada perusahaan Korea. Salah satunya adalah karir yang lebih cepat, hal tersebut diharapkan akan merubah mindset dari crew kapal asal Indonesia untuk bekerja bukan semata-mata mencari uang, tetapi perlu diperhatikan juga untuk karir yang gemilang kedepannya. Langkah lain yang perusahaan lakukan adalah memberi saran kepada ship owner dengan menyampaikan keluhan-keluhan crew Indonesia kepada owner Korea sehingga dapat memenuhi keinginan dari crew asal Indonesia.

\section{KESIMPULAN}

\section{A. Kesimpulan}

Berdasarkan hasil penelitian di lapangan serta dari hasil uraian pembahasan mengenai analisis mekanisme replacement crew kapal guna memperlancar crewing management di PT. Jasindo Duta Segara, maka dapat di ambil kesimpulan sebagai berikut: 
1. Kendala-kendala yang dihadapi pada pelaksanaan mekanisme replacement crew kapal guna memperlancar crewing management di PT. Jasindo Duta Segara adalah:

a. Control waiting list kapal yang belum rapi.

b. Permintaan crew kapal yang mendadak.

c. Pengarsipan masih dengan sistem filing cabinet dan kardus.

d. Sedikitnya minat crew kapal untuk berkerja pada perusahaan Korea.

2. Upaya yang dilakukan untuk mengatasi kendala-kendala yang dihadapi pada pelaksanaan mekanisme replacement crew kapal guna memperlancar crewing management di PT. Jasindo Duta Segara adalah:

a. Mengupdate waiting list crew secara teratur.

b. Membuat kebijakan kepada ship owner agar permintaan replacement crew kapal dikirimkan dua bulan sebelum masa keberangkatan crew pengganti.

c. Pengarsipan dokumen menggunakan sistem scan dan pengelompokan soft file berdasarkan jabatan.

d. Menjelaskan dan menyakinkan kepada crew kapal mengenai keuntungan bekerja pada perusahaan Korea dan memberikan masukan ke ship owner sebagai bahan evaluasi.

\section{B. Saran}

Saran yang peneliti sampaikan adalah sebagai berikut:

1. PT. Jasindo Duta Segara seharusnya menerapkan sistem database dalam crewing management agar dalam penyimpanan/pengarsipan data menjadi lebih terstruktur, pencarian data lebih cepat, akurat dan aman dalam penyimpanan.

2. Untuk mengantisipasi permintaan crew mendadak, PT. Jasindo Duta Segara harus mempunyai crew stand by dengan melakukan perekrutan pada jabatan yang tidak tersedia dalam waiting list crew meskipun belum ada permintaan replacement crew kapal dari ship owner.

3. Perlu dihilangkan kegiatan penjemputan crew sign off ke bandara yang bertujuan penahanan dokumen agar crew sign off tidak kabur, karena telah dilakukan penundaan gaji di bulan terakhir yang dibayarkan setelah crew sign off melapor ke perusahaan.

\section{DAFTAR PUSTAKA}

Darminto, Dwi Prastowo. 2012. Analisis Laporan Keuangan: Konsesp dan Manfaat. Yogyakarta : AMP-YKPN

Hadi, Sutrisno. 2015. Metodologi Research. Yogyakarta : Andi Offset

Kokasih, Engkos dan Soewedo, Hananto. 2014. Manajemen Perusahaan Pelayaran. Semarang

Marnis, Priyono. 2015. Manajemen Sumber Daya Manusia. Sidoarjo : Ziatma Publisher

Winarto. 2014. Mekanisme, http://definisimenurutparaahli.com$\underline{\text { mekanisme }}$

Nasution. 2013. Metode Research. Jakarta : Bumi Akasara

Peraturan Menteri Perhubungan Republik Indonesia Nomor PM 84, 2013, Perekrutan dan Penempatan Awak Kapal. Jakarta

Sarwono, Jonatan. 2016. Metodologi Penelitian Kualitatif dan Kuantitatif. Yogyakarta : Graha Ilmu

Sukardi. 2013. Metode Penelitian Pendidikan. Jakarta : Bumi Akasara

Undang-undang RI. 2008. Pelayaran. Jakarta 